\title{
Türk Öğrencilerin Çince Okuduğunu Anlama Becerisi Gereksinim Çözümleme Çalışması*
}

\section{Turkish Students' Needs Analysis for Chinese Reading Comprehension Skills}

\author{
İsmigül CANTÜRK ${ }^{1}$
}

* Bu çalışma "Çincede Okuduğunu Anlama Becerisine Yönelik Bir Ders Aracı Geliştirme Çalışması" başııkı doktora tezinden üretilmiş̧tir.

'Düzce Üniversitesi, Hakime Erciyas Yabancı Diller Yüksekokulu, Düzce, Türkiye

\section{ORCID: I.C. 0000-0001-8827-3449}

Sorumlu yazar/Corresponding author: İsmigül CANTÜRK (Dr. Arş. Gör.), Düzce Üniversitesi, Hakime Erciyas Yabancı Diller Yüksekokulu, Düzce, Türkiye

E-posta: ismigulavci@duzce.edu.tr

Başvuru/Submitted: 04.06 .2021

Revizyon Talebi/Revision Requested: 30.07.2021

Son Revizyon/Last Revision Received: 08.08.2021

Kabul/Accepted: 10.08 .2021

Atıf/Citation: Canturk, Ismigul. "Türk Öğrencilerin Çince Okuduğunu Anlama Becerisi Gereksinim Çözümleme Çalışması". Şarkiyat Mecmuası - Journal of Oriental Studies 39 (2021), 83-107.

https://doi.org/10.26650/jos.947796
Öz

Bu çalışmanın amacı, Çince öğretiminde dört temel dil becerilerinden biri olan okuma-anlama dersi için, Türkiye'de lisans düzeyinde eğitim gören öğrencilerin gereksinimlerini belirlemektir. Öğrenci gereksinimleri için mezun öğrenci, öğretmen ve yabancı uyruklu öğrencilerin görüşlerine başvurulan bu çalışmada, sormaca ve görüşme teknikleri kullanılmıştır. Araştırmanın çalışma grubu Çince lisans programlarından 121 Türk öğrenci, 79 Çince öğrenen farklı anadile sahip öğrenci, 6 Türk öğretmen, 10 anadil konuşucusu öğretmen ve 10 mezun öğrenciden oluşmaktadır. Sormaca yoluyla elde edilen veriler, frekans ve yüzde değerleri alınarak hesaplanmıştır. Ayrıntılı oluşturulan sormaca ve görüşme sonuçlarından elde edilen bulgular değerlendirilerek Türk öğrencilerin gereksinimleri belirlenmiştir. Araştırma sonucunda, okumaanlama derslerinde öğretmenler, okuma-anlama becerisinin geliştirilmesi için strateji ve tekniklerle dolu etkinliklere öncelik vermelidir. Mezun öğrenciler de aynı görüşü desteklemektedir. Çok sayıda çeşitli etkinliklerle strateji ve teknik farkındalığının arttıııması gerekir. Öğrencilerin stratejilerin öneminin farkında olmalarına rağmen yeterli strateji, teknik kullanmadıkları görüşme sonuçlarından anlaşılmıştır. Belirlenen öğrenci gereksinimleri, dil öğretiminin temeli kabul edilen okuma-anlama becerisine ilişkin yapılan çalışmalara, dersi veren öğretmenlere daha ayrıntılı ve öğrenciye odaklanan ders izlenceleri hazıllamaları ve uygulamaları açısından faydalı olacağı düşünülmektedir. Çalışmada yapılan gereksinim çözümleme okuma-anlama becerisinin kazandırılması ve öğrenme çıktılarının hedeflenen düzeye ulaşmasına olanak sunacağı düşünülmektedir. Anahtar kelimeler: Yabancı dil olarak Çince, Okuma-anlama becerisi, Gereksinim çözümleme

\section{ABSTRACT}

This study determines student needs for Chinese reading comprehension skills, one of the four basic language skills in teaching Chinese as a foreign language at the undergraduate level. Questionnaires and open-ended interviews were used for data collection, and graduate students, teachers, and foreign students were consulted about students'needs. The study group consisted of 121 Turkish students from Chinese undergraduate programs, 79 students with different native languages learning Chinese, 6 Turkish teachers, 10 native language 
speakers, and 10 students in Chinese graduate programs. Questionnaire findings were calculated as frequencies and percentages. Students' needs were determined by evaluating the detailed questionnaires and interview results. Results indicated that teachers should prioritize activities with varied strategies and techniques for development of reading comprehension skills. Graduate students supported these results. Strategies and reading-technique awareness needs to be increased through a large number of varied activities. Although students were aware of strategies' importance, interview results revealed their strategies and techniques to be inadequate. Knowledge of students' needs, as determined in this study, will benefit instruction in comprehension skills-accepted as the basis of language teaching-to help teachers prepare and implement a more detailed, student-focused syllabus. Finally, the needs analysis will enhance students' acquisition of reading comprehension skills and facilitate learning outcomes to reach the targeted level.

Keywords: Teaching Chinese as a foreign language, Reading comprehension skills, Needs analysis

\section{EXTENDED ABSTRACT}

Besides listening, reading is a receptive skill. As one of four skills, reading is crucial for literacy.

Reading is defined as voicing written symbols and reaching meaning, while reading comprehension is defined as more complex processes: comprehension, interpretation, and synthesis. Lapp and Flood (1986) assert that comprehension has three levels: (1) literal comprehension (reading the lines), (2) inferential comprehension (reading between the lines), and (3) critical comprehension (reading beyond the lines). In general, reading is a complex information processing skill by which the reader interacts with the text to comprehend it and to create a meaningful context. According to Grabe and Stoller (2011), reading consists of fluency, interaction, strategy, purpose, comprehension, learning, and linguistic processes. Furthermore, various sub-skills are required for successful reading. General purposes of reading are to search for simple information, to skim, to search for information for needs, to learn from text, and to read for general comprehension. To achieve these purposes, learners must practice basic reading skills, strategies, and techniques.

Chinese is usually called a logographic writing system because in written Chinese, the basic units are characters, typically morphemes. While many Chinese characters are free morphemes or words themselves, the number of characters is finite, and most Chinese words are multimorphemic and represented by multiple characters in print. Teaching and improving reading and reading comprehension skills in a non-alphabetic language such as Chinese is possible with planned and language-specific studies. Since different types of students have different language needs, course content and the program should correspond with student needs.

Needs analysis involves determination of materials, methods, strategies, and techniques appropriate for language content and the learning process to be used with a certain learner group. Needs analysis is thus a process of determining learners' needs and arranging the program according to the needs. In teaching Chinese as a foreign language in an academic context, needs analysis is a necessary component for designing a syllabus, tasks, materials, and evaluations. According to Long (2005), the determination of learner needs in foreign language teaching is a prerequisite that has become increasingly important for efficient course design. 
The present study aims to determine students' needs and teacher opinions for learning Chinese as a foreign language at the undergraduate level in Turkey. For the study, opinions of native-speaker teachers, Turkish teachers, graduate Turkish students, and students with different native languages were investigated using a questionnaire and standardized openended interviews as data collection techniques. Study participants were 121 Turkish students, 6 Turkish teachers, 10 graduate students, 10 native-speaker teachers, and 79 students with different mother tongues learning Chinese. To analyze the data, percentages and frequencies were used for questionnaire responses and a code system for interview transcripts. Information collected from interviews identified the necessary reading skills and strategies that students should achieve.

Major findings were that the majority of students searched unknown words before reading and that they need new, varied strategies for pre-reading. Strategies and reading-techniques awareness needs to be increased through a large number of various activities. Although students were aware of strategies' importance, interview results revealed that their strategies and techniques were inadequate. Recommendations include using varied reading strategies in pre-reading, required reading materials with varied content areas and varied text types, and reading materials selected according to students' individual interests. 


\section{Giriş}

Yabancı dil öğretimi programlarında, okuma ve dinleme becerileri, anlama erişimin yazı ve söylem yoluyla gerçekleşmesi nedeniyle alıcı beceriler olarak sınıflandırılır. ${ }^{1}$ Okuduğunu anlama becerisi, anlamlı girdi sağlayan alıcı becerilerden olmakla birlikte, diğer dil becerileri arasında görece daha geliştirici özelliğe sahiptir. Okuma, öğrencilere geniş sözvarlığı, dilbilgisi sunar ve okuduklarından hareketle bir metnin nasıl oluşturulacağını gösterir. Okuma, sadece yazma becerisini geliştirmekle kalmaz aynı zamanda diğer tüm beceri yetkinliklerini arttırır (Krashen 1982). ${ }^{2}$

Genel anlamda okuma, yazılı sembolleri seslendirme ve anlama ulaşma olarak tanımlanırken okuduğunu anlama ise kavrama, yorumlama ve sentezleme olarak daha karmaşık bir süreçler olarak tanımlanır. Grabe ve Stoller (2011)'e göre okuma akıcılık, etkileşim, strateji, amaç, kavrama, öğrenme ve dilsel süreçlerden oluşur ve başarılı okur olmak için çeşitli alt-beceriler gerekir. ${ }^{3} \mathrm{Bu}$ alt-beceriler çeşitli özelliklere göre sınıflandırılmıştır. Okuma alt-becerileri öğrenilen dilin ortografik yapısına göre farklılık gösterse de sözcük tanıma için çözümleme yapma, seslendirme ve sözcükleri otomatik tanıma okumanın ilk basamağı kabul edilir. Sözcük ve tümce seviyesinden dilsel bilgi yoluyla anlam çıkarma, tümce anlamları metin bağlamına göre birleştirip anlama. Basit anlama düzeyinden sonra ise kavramaya yardımcı söylem yapılarını anlama, okuma için çeşitli okuma stratejilerini kullanma, artalan bilgilerini kullanma, eleştirel okuma, değerlendirme, yorumlama ve sentezleme olarak üst bilişsel becerilere doğru ilerler.

Alfabetik olmayan dillerden olan Çincede okuma ve okuduğunu anlama süreci, Çincenin yazı sistemi ve biçimbilimsel yapısına bağlı olarak im, parça ve sözcük düzeyinde ve metin düzeyinde olarak incelenir. Çincenin en temel dil özelliklerinden biri yazı sisteminin imlere dayanması, çok sayıda tek heceli eş sesli sözcüğün bulunması ve dört ses tonunun bulunmasıdır. Dolayısıyla sesli okumada ses tonları anlam belirleyici olarak oldukça önemlidir. Yazılı sözcükleri okuma ve okuduğunu anlama alfabetik dillere göre oldukça karmaşık bir işlemleme süreci gerektirir. İm yapısal özelliklerinin çizgi, parça ve sözcük düzeyinde öğrenilirken aynı zamanda sesletim ve ses tonunun birlikte düşünülür. Çincede im-ses arasında bağlantı alfabe olmaması nedeniyle okumayı kolaylaştırıcı role sahip değildir.

Dil öğretiminin temel becerilerinden biri olan okuma becerisi, okur-yazar olmak için oldukça önemlidir. Çince gibi alfabetik olmayan bir dilde okuma ve okuduğunu anlama becerisinin öğretilmesi ve geliştirilmesi planlı ve dile özel çalışmalar yapılması ile mümkündür. Çince dil öğretim programı hazırlanırken öncelikle mevcut sistemdeki problemlerin, eksikliklerin belirlenmesi ve ihtiyaçların, isteklerin tespit edilmesi gerekir. Öğrencilerin, öğretmenlerin ve eğitim kurumlarının eksikleri ve ihtiyaçları hakkında bilgi sahibi olunarak ancak bu ihtiyaçları karşılamaya yönelik çalışmalar yapılabilir. Bu bağlamda kullanılan gereksinim çözümleme yöntemi, 1970’lerden sonra büyük önem kazanmış ve öğrenme amaçlarını belirlemede ilk adım olarak kabul edilmiştir.

1 J. Harmer, The Practice of English Langugae Teaching, England: Pearson Education Limited, 2007, s.265.

2 S. D. Krashen, Principles and Practice in Second Language Acquisition, Pergamon Press, 1982.

3 W. Grabe \& F. L. Stoller, Teaching and Researching Reading (2nd ed.). Great Britain: Pearson, 2011, s..9. 
Brown (2001), dil programlarında gereksinim çözümleme uygulamasının, öğrencilerin dil öğrenme ihtiyaçları için gerekli tüm bilgilerin toplanması ve analiz edilmesi olarak kabul edildiğini fakat programda bulunan öğretmen, yönetici, işverenlerin de ihtiyaçlarını kapsaması gerektiğini ifade eder. ${ }^{4}$ Hutchinson ve Water (1991) eğitimde ihtiyacı hedef ihtiyaçlar (öğrencinin hedef ihtiyaçlarının ne olduğu) ve öğrenme ihtiyaçları (dili nasıl öğrendikleri) olmak üzere iki gruba ayırmıştır. Hedef ihtiyaçlar gereksinimler, eksikler ve istekler olarak incelenirken, öğrenme ihtiyaçları dil becerilerini, stratejileri, işlenecek konuları vb. içerir. ${ }^{5}$

Gereksinim çözümleme için farklı değişkenlere bağlı olarak sistematik bir yaklaşım ve ayrıntılı çalışma gerektirir. Aynı grup içinde farklı dil öğrenme beklentilerinin olması, öğretim planlamasında gereksinim çözümlemeye ne kadar bağlı kalınabileceği sorununu ortaya çıkarır ve bu durum eğitim kurumunun amacına, dil hedeflerine uygun hale getirilerek çözülebilir. Gereksinim çözümleme ancak eğitim kurumlarının ilkelerine, öğretim ortamlarına, öğrenci hedef gereksinimlerine göre hazırlanıp değerlendirilerek yapılabilir. Yabancı dil öğretiminde gereksinim çözümlemeler, yarı yapılandırılmış görüşme ve daha yaygın şekilde yazılı sormacalar ile yapilır. ${ }^{6}$

Gereksinim çözümleme amaçları üçe ayrılır:

1. Öğretim planlama sürecinde öğrenciler, öğretmenler, yöneticiler ve işveren aracıllğıyla, dil programının içeriğinin düzenlemesi ve uygulanması için bilgi toplamak.

2. Dil programı için amaçlar, hedefler ve içerik olarak genel veya özel dil gereksinimlerini belirlemek.

3. Mevcut programın gözden geçirilmesi ve değerlendirilmesi için bilgi sağlamak. ${ }^{7}$

\section{1. Çalışmanın Amacı}

Bu çalışmada, Çince okuma-anlama becerisine ilişkin Türk öğrencilerin gereksinimlerini belirlemek amaçlanmıştır. Belirtilen amaçlar doğrultusunda aşağıdaki sorulara yanıt aranmıştır.

1. Öğrencilerin okuma-anlama becerisine ilişkin gereksinimleri nelerdir?

2. Çince programlarında çalışan öğretmenlerin okuma-anlama derslerine ilişkin görüşleri nelerdir?

a) Anadil konuşucusu öğretmenlerin okuma-anlama derslerine ilişkin görüşleri nelerdir?

b) Türk öğretmenlerin okuma-anlama derslerine ilişkin görüşleri nelerdir?

3. Çince programlardan mezun olmuş ve halen Çinceyi kullanan mezun öğrencilerin okuma-anlama derslerine ilişkin görüşleri nelerdir?

4 J. D. Brown, Using Survey in Language Programs, Cambridge Language Teaching Library, 2001.

5 T. Huntchinson, \& A. Waters, English for Specific Purposes: A learning- centered approach, Newyork: Cambridge University, 1991, s. 55-62.

6 Long, Second Language Needs Analysis, s.19.

7 Richard, The Language Teaching Matrix, s.1-2. 


\section{Yöntem}

Bu çalışmada, araştırmanın amacına uygun veri toplamak amacıyla karma yönteme göre sormaca, görüşme ve tarama teknikleri kullanılarak gereksinim çözümleme yapılmıştır. Nitel veriler görüşme, kaynak inceleme; nicel veriler ise sormacalar yoluyla toplanmıştır. Görüşmeler, röportajlar ve sormacalar dil programlarında ihtiyaçları bütünüyle tanımlamaya olanak sağlarken hedeflerin ve görevlerin belirlenmesini kolaylaştırır. ${ }^{8}$

Karma yöntemin amaçları üçgenleme, tamamlayıcılık, gelişim, başlangıç ve genişletme olmak üzere beş başlıkta sınıflandırılır. Karma yöntemde bu amaçlardan biri veya birkaçı bulunur. ${ }^{9}$

- Çeşitleme (Triangulation), aynı konuya ilişkin farklı sorularla nitel ve nicel verilerin birlikte toplanması sonucu, veriler kontrol edilir ve değerlendirilir.

- Tamamlayıcılık (Complementarity), aynı konuya ilişkin verilerin detaylandırılması ve farklı veya benzer boyutların ortaya çıkarılması amacıyla nitel ve nicel yöntemler kullanılır. Yabancı dil olarak Çince öğretiminde daha anlamlı ve bütüncül sonuçlara ulaşmak için araştırmacılar tamamlayıcı özelliği kullanılır. ${ }^{10}$

- Gelişim (Development) nitel ve nicel veriler sıralı şekilde toplanır ve ilk teknik ikinciye bilgi sağlayarak araştırmayı derinleştirir.

- Başlangıç (Initiation) karmaşık çalışmalarda nitel ve nicel veriler yeni görüşlerin, karşıt görüşlerin çıkmasını sağlar.

- Genişletme (Expansion) nitel ve nicel veriler çalışmanın farklı olguları için kullanılır.

Çeşitleme tekniği gözlem, görüşme, test etme, sormaca gibi farklı araştırma planlaması ile geniş ve güçlü veri toplanmasını sağlar. Çalışmamızın veri toplama sürecinde, karma yöntem amaçlarına göre, öncelikle çeşitleme olmak üzere tamamlayıcılık, gelişim tekniklerinden yararlanılmıştır. Aynı konu üzerinde çeşitli teknikler kullanılarak geniş verilere ulaşılmaya çalışılmıştır.

\subsection{Veri Toplama Teknikleri}

Bu çalışmada araştırma soruları doğrultusunda benzer içerikli üç farklı sormaca öncelikle pilot uygulamaları yapılarak kullanılmıştır. Sormaca, araştırma yöntemlerinde belirli konulara ilişkin düşünce, görüş ve varsayımları toplamak amacıyla kullanılan bir tekniktir. Sormacalar, çok sayıda kişiye ulaşılarak standart ölçülebilir sonuçlar elde edilmesi nedeniyle oldukça sık başvurulan araştırma tekniğidir. ${ }^{11}$

8 A. S. Grier, "Integrating needs assesment into career and technical curriculum development", Journal of Industrial Teacher Education 42(1):59-66, 2005.

9 J. C. Greene, V. J. Caracelli, \& W. F. Graham, "Toward a Conceptual Framework for Mixed-Method Evaluation Design", Educational Evaluation and Policy Analysis, 11(3):255-274, 1989.

10 F. Liang, "Adopting mixed methods for research topics in teaching Chinese as a second/foreign language", RTCFL, 2(2): 109-122, 2016.

11 Long, Second Language Needs Analysis, s.27. 
Problem durumunun belirlenmesi, mevcut durumun ortaya konulması ve öğrenci gereksinimlerinin belirlenmesi amacıyla, mevcut okuma-anlama dersleri, okuma yaklaşımları, tercih ettikleri sınama türleri, kullandıkları okuma stratejileri ve teknikleri, tercih ettikleri metin türleri ve kullanılan ders araçlarına ilişkin sorular içeren benzer içerikli üç farklı sormaca hazırlanmıştır. Sormacanın biçimine, temel bölümlerine karar vermek, soruları oluşturmak, doğru şekilde sıralamak, yönergeler yazmak ve pilot uygulama ile değerlendirme yapmak iyi bir sormaca hazırlamanın aşamalarıdır. ${ }^{12}$

Taslak olarak hazırlanan sormaca, "öğrencilerin okuma-anlama becerilerine ilişkin gereksinimleri nelerdir" sorusuna cevap aramak amacıyla, çalışma dışında tutulacak olan dördüncü sınıfta okumakta olan 7 öğrenciye uygulanmış, öğrenci eleştiri ve görüşleri dikkate alınarak sorular üzerinde düzeltmeler yapılmış ve pilot uygulama için sormaca tekrar düzenlenmiştir.

Pilot öğrenci sormacasında, demografik sorular hariç biri açık uçlu toplam 20 çoktan seçmeli soru yer almaktadır. Hazırlanan sormacalar üçüncü sınıftan 19 öğrenciye, dilbilgisi dersi sırasında, uygulanmış ve derste bulunmayan öğrencilerden 6'sı ise elektronik posta yoluyla sormacayı yanıtlamıştır. Anketlerin tamamlanması için derste öğrencilere 20 dakika süre verilmiştir. Yönergelerin anlaşılabilirliği kontrol edilmiş, seçenek önerilerine ilişkin öğrencilerin fikirlerine ulaşılmış ve pilot uygulama tamamlanmıştır.

Derslerin düzenlenişi ve işlenişi açısından büyük sorumluluklara sahip öğretmenlerin okumaanlama dersleri, kaynakları ve mevcut derslere ilişkin görüşlerinin alınması ve çalışmamızın “öğretmenlerin görüşleri nelerdir” sorusuna cevap bulunması amacıyla, Türkiye'de lisans düzeyinde ders veren öğretmen evreninin az olması nedeniyle, Çince programlarında çalışan toplam 10 öğretmene ikinci sormaca uygulanmıştır. 3 öğretmen ile yüz yüze görüşülmüş, maddeler hakkında fikirleri alınmıştır. 7 öğretmene ise sormacalar elektronik posta yoluyla gönderilmiş ve yanıtlar toplanmıştır. Sormacalar yüz-yüze görüşme imkânı olmayan durumlarda e-posta yoluyla da uygulanır. ${ }^{13}$ Öğretmen sormacasında, demografik sorular hariç, 14 çoktan seçmeli ve üç tane açık uçlu toplam 17 soru bulunmaktadır.

Öğrencilere yönelik hazırlanan gereksinim çözümleme sormacası temel alınarak, "mezun öğrencilerin görüşleri nelerdir" sorusuna da cevap aranmıştır. Mezun öğrencilere, mezun olduktan sonra Çince okuma-anlama becerisinde yaşadıkları sorunlar ve eksikliklerin neler olduğu, geriye dönük olarak okuma-anlama derslerinin nasıl olmasını isteyecekleri” şeklinde sorular hazırlanarak uygulanmıştır. Mezun öğrencilere yönelik hazırlanan sorularda, Çin'de aldıkları eğitime dair sorular da yer almaktadır. Çeşitli açık uçlu soruların bulunduğu sormacada, demografik sorular hariç 4 açık uçlu, 11 çoktan seçmeli toplam 15 madde bulunmaktadır. Mezun olduktan sonra Çinceyi kullanan ve farklı sektörlerde çalışan toplam 24 kişiye ulaşılmıştır.

12 Z. Dörnyei, Questionnaires in Second Language Research: Construction, Administration and Processing, London: Lawrence Erlbaum Associates P. 2003, s.16.

13 Long, Second Language Needs Analysis, s.45. 
Pilot uygulaması tamamlanan öğrenci ve öğretmen sormacaları, Nanjing Eğitim Üniversitesi'nde alanyazın taraması ve Çinli uzman görüşleri ile Çinceye çevrilmiştir. Bu süreçte Çinli uzmanlardan görüş alınmış, Çince okuma-anlama derslerine ilişkin hazırlanan Çince ölçeklerden yararlanılmış, alan yazında yapılan farklı çalışmalar incelenmiş ve farklı anadil konuşucusu öğrenciler bulunması nedeniyle yeni maddeler yazılmıştır.

Çince öğrenci veri toplama aracı olarak geliştirilen sormacada maddeler, demografik sorular hariç, dört bölümden oluşmaktadır. Oluşturulan maddeler aşağıda belirtilen başlıklar altında toplanmıştır. Bu araçta, aynı zamanda, kendi ülkelerinde uyguladıkları farklı ve etkili buldukları strateji, teknik veya etkinlikler var ise tespit etmek de hedeflenmiştir.

a. Genel Çince öğrenmelerine ilişkin görüşler

b. Mevcut Çince okuma-anlama derslerine ilişkin görüşler

d. Kendi ülkelerindeki eğitimlerinde varsa okuma-anlama derslerine ilişkin görüşler

Bu gruplandırmaya göre elde edilen veriler değerlendirilerek esas çalışmada Türk öğrencilerle kullanılmak üzere daha kapsamlı bir veri toplama aracının geliştirilmesi amaçlanmıştır. Uygulama, Nanjing Eğitim Üniversitesi Çin Dili ve Edebiyatı üçüncü ve dördüncü sınıf ve Çince dil kursu ikinci sınıf öğrencilerinden oluşan 79 öğrencinin katılımıyla gerçekleştirilmiştir.

Nanjing Eğitim Üniversitesi’nde görev yapan ve yabancı öğrencilerin derslerine giren 10 anadil konuşucusu öğretmenle yüz yüze görüşmüş ve Çince hazırlanan öğretmen sormacalarını yanıtlamaları istenmiştir. Sormacada iki açık uçlu 26 çoktan seçmeli olmak üzere toplam 28 madde bulunmaktadır.

\subsection{Görüşme}

Araştırmada iki farklı görüşme tekniği kullanılmıştır. Alan uzmanlarının görüşlerinin elde edilmesi amacıyla yarı yapılandırılmış görüşme ve mezun öğrencilerin görüşlerini almak amacıyla odak grup görüşme yapılmıştır.

\subsubsection{Odak Grup Görüşme}

Araştırmada, farklı sektörlerde çalışan, iş arayan ve Çince eğitime devam eden 10 mezun öğrenci ile 12 maddeden oluşan odak grup çalışmamız yüz yüze görüşme yöntemi ve wechat uygulaması aracılığıyla tamamlanmıştır. Odak grup görüşmeleri dört grup şekilde yapılmıştır. Üç doktora öğrencisi, iki özel sektörde çalışan ve iki iş arayan öğrenci odak grup görüşmemize katılmıştır. Mezun öğrencilerden beş kişi Sinoloji, beş kişi Çin Dili ve Edebiyatı mezunudur.

Mezun öğrenci odak grup görüşmeleri, kayıt altına alınarak değerlendirilmiştir. Görüşme çözümlemesi yapılmış, elde edilen kayda değer bilgiler, öneriler sormacalarda ve araç geliştirme sürecinde kullanılmak üzere çalışma amacına göre değerlendirilmeye alınmıştır. 


\subsubsection{Yarı Yapılandırılmış Görüşme}

Araştırmada Çince programlarında öğretmenlik yapan 6 kişi ile 14 maddeli açık uçlu sorudan oluşan yarı yapılandırılmış görüşme yapılmıştır. Görüşme soruları, araştırma sorularına ve alanyazın bilgilerine göre uzman görüşü alınarak hazırlanmıştır. Öğretmenlerden ikisi ilkokul, lisede Çince öğretirken, dört öğretmen üniversitede Çince programlarında Çince öğretmektedir.

Öğretmen ve mezun öğrenci sayılarının az olması nedeniyle esas çalışmada Türk öğretmen ve mezun öğrenci sormacası yapılmamış; mezun öğrencilerle odak grup ve öğretmenlerle ise yarı yapılandırılmış görüşme yapılmıştır. Odak grup çalışması, yarı yapılandırılmış görüşme, pilot uygulamalardan elde edilen veriler ve Çince alanyazın taraması ile öğrenci gereksinim çözümleme sormacasında gerekli değişiklikler yapılmıştır.

\subsection{Verilerin Çözümlemesi}

Araştırma soruları doğrultusunda veriler nitel ve nicel tekniklerden yararlanılarak çözümlenmiştir. Türk öğrenci gereksinim çözümleme sormacalarının çözümlemesinde SPSS (Sosyal Bilimsel İçin İstatistik Programı) 22.0 paket programı kullanılmıştır. Yanıtların yüzdelik dilimleri hesaplanarak sonuçlar tablolar halinde sunulmuştur.

Farklı anadile sahip Çince öğrenen öğrencilerinin sormacası ve anadil öğretmen sormacalarının, sayısal değerleri düşük olması nedeniyle yüzdelik ve frekans değerlendirilmesi yapılmamış, okuma alanyazına göre belli kavram ve temalar çerçevesinde betimsel analiz tekniği ile değerlendirilmiş̧tir.

Yapılan öğretmen ve öğrenci görüsşmeleri ses kaydı yoluyla kaydedilerek içerik çözümlemesi yapılmıştır. İçerikte bulunan benzer içerikler, kayda değer veriler ortaya çıkarılıp tanımlanmıştır. Araştırma sorularına göre belirlenen temalara göre görüşlere ulaşılmaya çalışılmıştır.

Bu bölümde, çalışmamızın amacı doğrultusunda toplanan öğrenci gereksinimlerinin çözümlenmesi, öğretmen ve mezun öğrenci görüşleri verilerine ilişkin bulguları yer almaktadır. Araştırmanın öğrenci gereksinim çözümleme verileri, istatistiksel olarak SPSS programı ile çözümleme yapılarak ve görüşme verileri çözümlenerek sunulmuştur. Bulgular, araştırma sorularına paralel olacak şekilde ele alınmıştır. Bu bölümde araştırma verilerinden Türk öğrenci bulguları sunulurken, öğretmen ve mezun öğrenci bulguları yorumları ile birlikte sunulmuştur.

\section{Bulgular}

\subsection{Türk Öğrenci Gereksinim Çözümleme Bulguları}

Öğrenci gereksinim çözümleme sormacası Ankara Üniversitesi Sinoloji bölümü ve Okan Üniversitesi Çince Mütercim Tercümanlık bölümünden toplam 121 öğrenciye uygulanmıştır. Öğrencilerin okuma-anlama derslerine, ders araçlarına, ders uygulamalarına ilişkin gereksinimleri sormaca tekniği ile belirlenmeye çalışılmıştır.

Araştırma kapsamında 121 öğrenciden toplanan anket verilerinin tümü kategoriktir. Öğrencilerin anket sorularında verilen kategorilere dağılımını belirlemek için frekans ve 
yüzde hesaplanmıştır. Kayıp veri olduğu durumlarda kayıp veriler analizden çıkarılarak kalan verilerle analiz yapılmıştır. Bazı sorularda öğrencilere birden fazla kategoriyi seçebilme olanağ verilmiştir. Bu sorularda ilgili kategoriyi seçen öğrencilerin yüzdesi, toplam öğrenci sayısına göre belirlenmiştir. Tablolar oluşturulurken okuma kolaylığı sağlanması amacıyla seçenekler yüzde ve frekanslarına göre büyük değerden küçük değere doğru sıralanmıştır.

\section{A Bölümü}

Araştırmaya katılan öğrencilerin Çinceyi öğrenmeye başlama yaşına göre dağılımı Tablo 1 'de verilmiştir.

Tablo 1. Öğrencilerin Çinceyi Öğrenmeye Başlama Yaşına Göre Dağılımı

\begin{tabular}{|l|c|c|}
\hline Yaş & $\mathbf{N}$ & $\mathbf{\%}$ \\
\hline 18 ve altı & 60 & 49.60 \\
\hline $19-22$ & 51 & 42.10 \\
\hline 27 ve üstü & 6 & 5.00 \\
\hline $23-26$ & 4 & 3.30 \\
\hline Toplam & 121 & 100 \\
\hline
\end{tabular}

Tablo 1'de görüldüğü üzere öğrencilerin \% 49.60'1 18 yaş ve altı yaşlarda, \% 42.10'u 1922 yaş arasındayken, \% 3.30'u 23-26 yaş arasındayken ve \% 5'i 27 ve üstü yaşlarda Çince öğrenmeye başlamışlardır. Öğrencilerin büyük çoğunluğunun (\% 91.70) 23 yaşından önce Çince öğrenmeye başladıkları görülmektedir. Öğrenciler, Çince öğrenmeye farklı sebeplerden başlamaktadırlar. Bu sebepler Tablo 2'de özetlenmiştir.

Tablo 2. Öğrencilerin Çince Öğrenmeye Başlama Sebebi

\begin{tabular}{|l|c|c|}
\hline Kategori & N & \% \\
\hline Kendi ilgi alanıma girdiği için seçtim. & 68 & 56.20 \\
\hline İs imkânları nedeniyle öğrenmeye karar verdim. & 30 & 24.79 \\
\hline Arkadaş, tanıdık önerisiyle karar verdim. & 9 & 7.44 \\
\hline Ailemin isteğiyle karar verdim. & 9 & 7.44 \\
\hline Diğer & 5 & 4.13 \\
\hline Toplam & 121 & 100 \\
\hline
\end{tabular}

Tablo 2 incelendiğinde, öğrencilerin yarısından fazlasının (\% 56.20) ilgi duydukları için Çince öğrenmeye karar verdikleri görülmektedir. Öğrencilerin \% 24.79'u ise iş olanakları nedeniyle Çince öğrenmeye karar verdiklerini belirtmişlerdir. Arkadaş önerisi ve aile isteği ile Çince öğrenmeye başlama yüzdesi diğer seçeneklere göre daha düşüktür.

Öğrencilerin Çince öğrenme sonucunda ulaşmak istedikleri hedefler de farklılık göstermektedir. Öğrencilerin Çince öğrenme amaçları Tablo 3 ’te verilmiştir. 
Tablo 3. Öğrencilerin Çince Öğrenme Amac1

\begin{tabular}{|c|c|c|}
\hline Kategori & $\mathbf{N}$ & $\%$ \\
\hline Özel sektörde tercüman olmak & 51 & 42.50 \\
\hline Ticaret yapmak & 29 & 24.17 \\
\hline Akademik kariyer yapmak & 22 & 18.33 \\
\hline Turizm sektöründe çalışmak & 10 & 8.33 \\
\hline Diğger & 6 & 5.00 \\
\hline Öğretmen olmak (lise-ortaokul-ilkokul) & 2 & 1.67 \\
\hline Toplam & 120 & 100 \\
\hline
\end{tabular}

Tablo 3'te görüldüğü üzere, öğrencilerin \% 42.50'si özel sektörde tercüman olmak, \% 24.17'si ticaret yapmak, \% 18.33'ü akademik kariyer yapmak, \% 8.33'ü turizm sektöründe çalışmak ve \% 1.67'si ise öğretmen olmak amacıyla Çince öğrenmektedir. Öğrencilerin Çince okuma-anlama ders planının hazırlanması süreci hakkındaki görüşleri Tablo 4'de özetlenmiştir.

Tablo 4. Öğrencilerin Çince Okuma-Anlama Ders Planının Hazırlanması Süreci Hakkındaki Görüşleri

\begin{tabular}{|l|c|c|}
\hline Kategori & N & \% \\
\hline Öğrencilerin talepleri ve ihtiyaçları dikkate alınmalıdır. & 87 & 72.50 \\
\hline HSK okuduğunu anlama soruları dikkate alınarak plan yapılmalıdır. & 18 & 15.00 \\
\hline Öğrencilere sormaya gerek yoktur. & 6 & 5.00 \\
\hline Çin'de hazırlanmış ders araçlarının kullanılması yeterlidir. & 5 & 4.17 \\
\hline Diğger & 4 & 3.33 \\
\hline Toplam & 120 & 100 \\
\hline
\end{tabular}

Tablo 4'e göre, öğrencilerin büyük çoğunluğu (\% 72.50) Çince okuma-anlama dersinin ders planı hazırlanırken kendi talep ve ihtiyaçlarının dikkate alınmasını istemektedir. Diğer taraftan, öğrencilerin \% 5'i ders planı hazırlanırken öğrencilerin görüşlerinin alınmasına gerek olmadığını düşünmektedir. Öğrencilerin \% 15'i ders planının HSK'ya uygun olarak hazırlanmasını istemektedir. Az sayıda öğrenci (\% 4.17) ise Çin'de hazırlanan ders araçlarını kullanmanın yeterli olacağını düşünmektedir.

Çince eğitimi gören katılımcı öğrencilerin Çince seviyesi hedefleri de farklılaşmaktadır. Öğrencilerin ulaşmayı hedefledikleri Çince seviyesine ilişkin görüşleri Tablo 5 'te verilmiştir.

Tablo 5. Öğrencileri Hedef Olarak Belirledikleri Çince Seviyesi

\begin{tabular}{|l|c|c|}
\hline Kategori & $\mathbf{N}$ & $\mathbf{\%}$ \\
\hline İyi derecede Çince konuşmak, yazmak ve okumak istiyorum. & 65 & 53.72 \\
\hline Çin dili ve edebiyatı araştırmaları yapabilecek kadar iyi seviyeye gelmek istiyorum. & 39 & 32.23 \\
\hline $\begin{array}{l}\text { İyi derecede Çince konuşmak ve okumak istiyorum fakat konuşma ve okuma becerimi } \\
\text { yeteri kadar geliştiremedim. }\end{array}$ & 12 & 9.92 \\
\hline $\begin{array}{l}\text { Konuşma ve dinleme becerisi benim için yeterli, okuma ve yazma üzerinde çok } \\
\text { çalısmama gerek yok. }\end{array}$ & 3 & 2.48 \\
\hline Diğer & 2 & 1.65 \\
\hline Toplam & 121 & 100 \\
\hline
\end{tabular}


Tablo 5 ’te görüldüğü üzere, öğrencilerin yarısından fazlası (\% 53.72) iyi derecede Çince konuşma, yazma ve okuma becerisine sahip olmak istemektedir. Öğrencilerin \% 32.33’ü ise Çin dili ve edebiyatı hakkında araştırma yapabilecek Çince seviyesine ulaşmayı hedeflemektedir.

Öğrencilerin mezun olurken ulaşmayı hedefledikleri HSK düzeyine ilişkin bildirimleri Tablo 6'da verilmiştir.

Tablo 6. Öğrencilerin Mezun Olurken Ulaşmayı Hedefledikleri HSK Düzeyi

\begin{tabular}{|l|c|c|}
\hline Düzey & $\mathbf{N}$ & $\mathbf{\%}$ \\
\hline HSK 6 & 64 & 53.33 \\
\hline HSK 5 & 49 & 40.83 \\
\hline HSK 4 & 7 & 5.83 \\
\hline Toplam & 120 & 100 \\
\hline
\end{tabular}

Tablo 6'da görüldüğü üzere, öğrencilerin \%5.83'ü HSK 4 düzeyine, \% 40.83'ü HSK 5 düzeyine ve \%53.33'ü HSK 6 düzeyi Çince becerisine sahip olarak mezun olmayı hedeflemektedir.

Öğrencilerin eğitim gördükleri eğitim kurumunda uygulanan programda eksik olarak gördükleri dil becerileri Tablo 7'de özetlenmiştir.

Tablo 7. Öğrencilerin Uygulanmakta Olan Programda Eksik Olarak Gördükleri Dil Becerileri

\begin{tabular}{|l|c|c|}
\hline Dil Becerisi & N & \% \\
\hline Konuşma/Sesletim & 55 & 45.45 \\
\hline Dinleme & 26 & 21.49 \\
\hline Yazma & 14 & 11.57 \\
\hline Dilbilgisi & 14 & 11.57 \\
\hline Okuma & 8 & 6.61 \\
\hline Konuşma/Sesletim ve Dinleme & 3 & 2.48 \\
\hline Konuşma/Sesletim, Okuma ve Dinleme & 1 & 0.83 \\
\hline Toplam & 121 & 100 \\
\hline
\end{tabular}

Tablo 7'de göre, öğrencilerin \% 45.45'i programda Çince konuşma becerisine yeterince yer verilmediğini düşünmektedir. Bu beceriyi \% 21.49 ile dinleme becerisi takip etmektedir. Programda yazma ve dilbilgisi becerisi eksik diyenlerin yüzdeleri eşittir (\% 11.57). Öğrencilerin çok az bir bölümü (\% 6.61) ise programda okuma becerisine yeterince yer verilmediğini düşünmektedir.

Öğrencilerin Çince eğitiminde hangi dil becerisine ağırlık verilmesi gerektiği konusundaki görüşleri Tablo 8'de verilmiştir. 
Tablo 8. Öğrencilerin Çince Eğitiminde Dil Becerilerinin Ağırlığına İlişkin Görüşleri

\begin{tabular}{|l|c|c|}
\hline Dil Becerisi & $\mathbf{N}$ & $\mathbf{\%}$ \\
\hline Eşit oranda yer verilmelidir & 73 & 60.33 \\
\hline Yazma & 19 & 15.70 \\
\hline Konuşma/Sesletim & 16 & 13.22 \\
\hline Okuma & 5 & 4.13 \\
\hline Dinleme & 3 & 2.48 \\
\hline Dilbilgisi & 3 & 2.48 \\
\hline Yazma ve Konuşma/Sesletim & 1 & 0.83 \\
\hline Dinleme ve Konuşma/Sesletim & 1 & 0.83 \\
\hline Toplam & 121 & 100 \\
\hline
\end{tabular}

Tablo 8'de görüldüğü üzere, öğrencilerin çoğunluğu (\% 60.33) yazma, konuşma, okuma, dinleme ve dilbilgisi becerilerine eşit ağırlık verilmesi gerektiğini düşünmektedir. Diğer taraftan yazma becerisine (\% 15.70) ya da konuşma becerisine (\% 13.22) ağırlık verilmesini gerektiğini düşünen öğrenciler de bulunmaktadır.

Öğrenciler bazı Çince dil becerilerine sahip olmayı daha zor görmektedirler. Öğrencilerin en zor Çince dil becerisinin ne olduğu hakkındaki görüşleri Tablo 9'da verilmiştir.

Tablo 9. Öğrencilerin Daha Zor Olarak Düşündükleri Çince Dil Becerisi

\begin{tabular}{|l|c|c|}
\hline Dil Becerisi & $\mathbf{N}$ & $\mathbf{\%}$ \\
\hline Konuşma/Sesletim & 46 & 38.33 \\
\hline Yazma & 45 & 37.50 \\
\hline Dinleme & 11 & 9.17 \\
\hline Dilbilgisi & 11 & 9.17 \\
\hline Okuma & 7 & 5.83 \\
\hline Toplam & 120 & 100 \\
\hline
\end{tabular}

Tablo 9'a göre, öğrencilerin \% 38.33'ü Çince konuşmayı, \% 37.50'si ise Çince yazmayı daha zor bulmaktadır. Okuma becerisinin daha zor olduğunu düşünen öğrenci yüzdesi en azdır (\% 5.83). Dinleme ve dilbilgisi becerilerini daha zor bulan öğrenci yüzdeleri eşittir.

Öğrenciler Çince çalışırken internetten farklı biçimlerde faydalanmaktadır. Öğrencilerin Çince çalışırken interneti kullanma biçimlerine ilişskin bulgular Tablo 10'da özetlenmiştir.

Tablo 10. Öğrencilerin Çince Çalışırken İnternetten Faydalanma Biçimleri

\begin{tabular}{|l|c|c|}
\hline Kategori & N & \%* \\
\hline Çince film izlerim, müzik dinlerim. & 84 & 69.42 \\
\hline Sohbet sitelerinde Çince konuşup yazışırım. & 43 & 35.54 \\
\hline Çince haberleri ve sosyal medyayı takip ederim. & 29 & 23.97 \\
\hline İlgimi çeken konuları Çince araştırırım. & 25 & 20.66 \\
\hline Çince hikâye, roman okurum ve dinlerim. & 19 & 15.70 \\
\hline Çince reklamları takip ederim. & 6 & 4.96 \\
\hline Diğer & 3 & 2.48 \\
\hline
\end{tabular}

*121 katılımcı arasından ilgili kategoriyi seçenlerin yüzdesidir. Katıllmcılar birden fazla kategoriyi seçebilmektedirler. 
Tablo 10'da görüldüğü üzere, araştırmaya katılan öğrencilerden \% 69.42'si Çince film izleyip müzik dinleyerek Çince çalışmaktadır. Öğrencilerin \% 35.54'ü Çincelerini geliştirmek için Çince sohbet sitelerini kullanırken, \% 23.97'si Çince haberleri ve sosyal medyayı takip etmektedir. Öğrencilerin \% 20.66'sı ilgileri çeken konuları araştırarak Çince çalışmaktadır. İnternet ortamındaki Çince hikâye ve romanlar aracılığıyla Çince çalışan öğrencilerin yüzdesi 15.70'dir. Öğrencilerin Çince çalışırken kullandıkları internet kaynaklarına göre dağılımı Tablo 11 'de verilmiştir.

Tablo 11. Öğrencilerin Çince Çalışırken Kullandıkları İnternet Kaynaklarına Göre Dağılımı

\begin{tabular}{|l|l|l|}
\hline Kategori & $\mathbf{N}$ & $\mathbf{\%}^{*}$ \\
\hline Youtube & 56 & 46.67 \\
\hline Baidu & 45 & 37.50 \\
\hline QQ, wechat, renrenwang & 37 & 30.83 \\
\hline Youku, tudou, QIY & 20 & 16.67 \\
\hline Wenku, baike & 15 & 12.50 \\
\hline Diğer & 14 & 11.67 \\
\hline
\end{tabular}

*120 katılımcı arasından ilgili kategoriyi seçenlerin yüzdesidir. Katıllmcılar birden fazla kategoriyi seçebilmektedirler.

Tablo 11'de göre, öğrencilerin yaklaşık yarısı (\% 46.67) Çince çalışmak için Youtube'u kullandıklarını belirtmişlerdir. İkinci olarak en çok kullanılan internet sitesi Baidu'dur (\% 37.50). Öğrencilerin \% 30.83'ü QQ, wechat ve renrenwang sitelerini; \% 16.67'si Youku, tudou ve QIY sitelerini; \% 12.50'si ise Wenku ve baike sitelerini kullanmaktadır. Bu bulguya göre öğrenciler evrensel bir video paylaşım sitesi olan Youtube'u, Çin'e özgü sitelerden daha sık kullanmaktadır.

\section{B Bölümü}

Öğrencilerin Çince okuduğunu anlama becerisine hangi durumlarda ihtiyaç duyabileceklerine ilişkin görüşleri Tablo 12'de özetlenmiştir.

Tablo 12. Öğrencilerin Çince Okuma-Anlama Becerisine İhtiyaç Duyabilecekleri Durumlar

\begin{tabular}{|c|c|c|}
\hline Kategori & $\mathbf{N}$ & $\% *$ \\
\hline Hepsi & 82 & 67.77 \\
\hline İş hayatında yazışmalarda ihtiyaç duyabilirim. & 29 & 23.97 \\
\hline Çin'de günlük yaşam içinde ihtiyaç duyabilirim. & 27 & 22.31 \\
\hline İnternet veya sosyal medyada ihtiyaç duyabilirim. & 12 & 9.92 \\
\hline Gazete, dergi, roman okumak için ihtiyaç duyabilirim. & 9 & 7.44 \\
\hline
\end{tabular}

*121 katılımcı arasından ilgili kategoriyi seçenlerin yüzdesidir. Katıllmcılar birden fazla kategoriyi seçebilmektedirler.

Tablo 12'de görüldüğü üzere, öğrencilerin \%23.97'si iş hayatındaki yazışmalarda, \% 22.31 'i Çin'de günlük yaşam içinde, \% 9.92'si internet ve sosyal medyada ve \% 7.44 'ü ise gazete, dergi ve roman okumak için Çince okuduğunu anlama becerisine ihtiyaç duyacağını 
düşünmektedir. Öğrencilerin büyük çoğunluğu (\% 67.77) ise bu dört durumun hepsinde Çince okuduğunu anlama becerisine ihtiyaç duyacaklarını düşünmektedir. Bu bulgu, dört kategorideki durumların hepsinin belirli düzeyde Çince okuma ve anlama becerisi gerektirmesinin doğal bir sonucu olarak düşünülebilir.

Öğrencilere göre, uygulanmakta olan ders programındaki derslerin ağırlık verdiği Çince okuma-anlama etkinlikleri Tablo 13 'teki gibidir. Ankara ve Okan Üniversitesindeki öğrencilere uygulanan ankette farklı etkinlikler yer aldığı için bu iki üniversite için sonuçlar ayrı verilmiştir.

Tablo 13. Programdaki Derslerin Çince Okuma-Anlama Etkinliklerine Verdikleri Ağırlığa Göre Dağılımı

\begin{tabular}{|l|l|c|c|}
\hline Üniversite & Okuma-Anlama Etkinliği & N & \%* \\
\hline \multirow{5}{*}{$\begin{array}{l}\text { Ankara } \\
\text { Üniversitesi }\end{array}$} & Tarihi Metinler & 22 & 28.21 \\
\cline { 2 - 4 } & Çin Tarihine Giriş & 18 & 23.08 \\
\cline { 2 - 4 } & Sözlü Anlatım & 18 & 23.08 \\
\cline { 2 - 4 } & Yazılı Anlatım & 16 & 20.51 \\
\cline { 2 - 4 } & Simultane Çeviri & 15 & 19.23 \\
\cline { 2 - 4 } & Çin Edebiyatı & 11 & 14.10 \\
\cline { 2 - 4 } & Komposizyon & 10 & 12.82 \\
\cline { 2 - 4 } & Diğer & 10 & 12.82 \\
\hline \multirow{5}{*}{$\begin{array}{l}\text { Okan } \\
\text { Üniversitesi }\end{array}$} & Yazılı Anlatım & 19 & 44.19 \\
\cline { 2 - 4 } & Sözlü Anlatım & 17 & 39.53 \\
\cline { 2 - 4 } & Kültür Çalışmaları & 10 & 23.26 \\
\cline { 2 - 4 } & Çeviri Amaçlı Dil Edinci & 9 & 20.93 \\
\cline { 2 - 4 } & Medya Çevirisi & 4 & 9.30 \\
\cline { 2 - 4 } & Çince Yazın & 3 & 6.98 \\
\cline { 2 - 4 } & Uzmanlık Metinleri & 2 & 4.65 \\
\cline { 2 - 4 } & Diğer & 1 & 2.33 \\
\hline
\end{tabular}

*Ankara Üniversitesinde 77 ve Okan Üniversitesinde 44 katılimcı arasından ilgili kategoriyi seçenlerin yüzdesidir. Katıllmcllar birden fazla kategoriyi seçebilmektedirler.

Tablo 13'e göre, Ankara Üniversitesinde Çince okuma-anlama etkinliklerinde tarihi metinlere ağırlık verildiğini düşünen öğrencilerin yüzdesi en fazladır (\% 28.21). Bu etkinliği sırasıyla Çin tarihine giriş, sözlü anlatım, yazılı anlatım, simultane çeviri, Çin edebiyatı ve kompozisyon takip etmektedir. Okan Üniversitesindeki öğrenciler ise en çok yazılı anlatıma (\% 44.19) ağırlık verildiğini düşünmektedirler. Sözlü anlatım ikinci sırada gelmektedir. Daha sonra sırasıyla kültür çalışmaları, çeviri amaçlı dil edinci, medya çevirisi, Çince yazın ve uzmanlık metinleri gelmektedir.

Araştırmaya katılan 121 öğrenciden 50'si ( \%41.32) eğitim gördükleri kurumda kullanılan Çince programındaki okuma-anlama etkinliklerini yeterli bulurken, 71'`i (\% 58.68) yeterli bulmamaktadır. Çince programındaki okuma-anlama etkinliklerini yeterli bulmayan 71 öğrencinin programda okuma-anlama etkinliklerini neden yeterli bulmadıklarına ilişkin görüşleri Tablo 14’te özetlenmiştir. 
Tablo 14. Öğrencilerin Çince Okuma-Anlama Etkinliklerini Yetersiz Bulma Sebepleri

\begin{tabular}{|c|c|c|}
\hline Kategori & $\mathbf{N}$ & $\% *$ \\
\hline Ders saati yetersiz & 31 & 43.66 \\
\hline Yapılan etkinlikler verimsiz. & 18 & 25.35 \\
\hline Etkili okuma strateji ve tekniklerinin kullanılamaması. & 18 & 25.35 \\
\hline Ders araçları yetersiz ve seviye uygun değil. & 15 & 21.13 \\
\hline Diğger & 3 & 4.23 \\
\hline
\end{tabular}

Tablo 14'te görüldüğüü üzere, öğrencilerin \% 43.66'sı Çince programındaki okuma-anlama etkinliklerinin yetersiz olmasını ders saatinin az olmasına bağlamaktadır. Okuma-anlama etkinliklerini yetersiz bulan öğrencilerin yaklaşık dörtte biri (\% 25.35) yapılan etkinliklerin verimsiz olduğunu düşünmektedir. Öğrencilerin \% 25.35'i kullanılan strateji ve tekniklerin etkisiz olduğunu düşünmektedir.

Öğrencilerin kendi Çince okuma-anlama seviyeleri hakkındaki görüşlerini belirlemek amaciyla sorulan anket sorusuna verdikleri cevaplar Tablo 15'te özetlenmiştir.

Tablo 15. Öğrencilerin Kendi Çince Okuma-Anlama Seviyeleri Hakkındaki Görüşleri

\begin{tabular}{|l|c|c|}
\hline Düzey & $\mathbf{N}$ & $\mathbf{\%}$ \\
\hline Orta & 60 & 49.59 \\
\hline İyi & 26 & 21.49 \\
\hline Emin değilim & 20 & 16.53 \\
\hline Kötü & 14 & 11.57 \\
\hline Çok iyi & 1 & 0.83 \\
\hline Toplam & 121 & 100 \\
\hline
\end{tabular}

Tablo 15'e göre, öğrencilerin yaklaşık yarısı (\% 49.59) kendi Çince okuduğunu anlama becerilerinin orta düzeyde olduğunu düşünmektedir. Okuduğunu anlama düzeyinin çok iyi olduğunu düşünen sadece 1 öğrenci bulunmaktadır. Ayrıca öğrencilerin \% 16.53’ü kendi okuduğunu anlama becerilerinin hangi düzeyde olduğu konusunda emin değildir. Öğrencilerin Çince okuma-anlama derslerinde öğretmen ve öğrenciden kimin daha fazla aktif olması gerektiğine dair görüşleri Tablo 16 ' da verilmiştir.

Tablo 16. Öğrencilerin Çince Okuma-Anlama Derslerinde Kimin Daha Aktif Olması Gerektiğine Dair Görüşleri

\begin{tabular}{|l|c|c|}
\hline Kategori & $\mathbf{N}$ & $\mathbf{\%}$ \\
\hline Öğrenci & 83 & 69.17 \\
\hline Farketmez. & 19 & 15.83 \\
\hline Öğretmen & 18 & 15.00 \\
\hline Toplam & 120 & 100 \\
\hline
\end{tabular}


Tablo 16’ya göre, öğrencilerin büyük çoğunluğu (\% 69.17) Çince okuma-anlama derslerinde öğrencilerin daha aktif olması gerektiğini düşünmektedir. Çince okuma-anlama derslerinde öğretmenin öncelik vermesi gerektiği konular hakkındaki öğrenci görüşleri Tablo 17'de özetlenmiştir.

Tablo 17. Çince Okuma-Anlama Derslerinde Öğretmenin Öncelik Vermesi Gerektiği Konular Hakkındaki Öğrenci Görüşleri

\begin{tabular}{|l|c|c|}
\hline Kategori & N & $\%^{*}$ \\
\hline Okuma-anlama becerilerinin geliştirmesi için strateji ve teknikleri & 72 & 59.50 \\
\hline Sözcük bilgisi & 44 & 36.36 \\
\hline Dilbilgisi & 38 & 31.40 \\
\hline Okuma metinleri içerik bilgisi & 32 & 26.45 \\
\hline Okuma metinleri tür bilgisi & 7 & 5.79 \\
\hline Diğer & 1 & 0.83 \\
\hline
\end{tabular}

*121 katılımcı arasından ilgili kategoriyi seçenlerin yüzdesidir. Katılımcılar birden fazla kategoriyi seçebilmektedirler.

Tablo 17'de görüldüğü üzere, öğrencilerin \% 59.60'1 okuduğunu anlama becerilerinin gelişmesine katkıda bulunacak strateji ve tekniklere ağırlık verilmesi gerektiğini düşünmektedir. Öğrencilerin \% 36.36'sı sözcük bilgisine, \% 31.40'1 dilbilgisine ve \% 26.45'i ise okuma metinleri içerik bilgisine öncelik verilmesi gerektiğini düşünmektedir.

Öğrencilere göre, Çince okuma-anlama derslerinde en sık yaptıkları etkinliklerin dağılımı Tablo 18'de verilmiştir.

Tablo 18. Çince Okuma-Anlama Derslerinde En Sık Yapılan Etkinlikler

\begin{tabular}{|l|l|l|}
\hline Kategori & N & \%* \\
\hline Metinle ilgili konuşma & 96 & 79.34 \\
\hline Tartışma & 12 & 9.92 \\
\hline Diyalog ezberleme & 10 & 8.26 \\
\hline Grup çalışması & 8 & 6.61 \\
\hline Rol yapma & 6 & 4.96 \\
\hline Oyun (sözcük oyunları vb.) & 5 & 4.13 \\
\hline Sorun çözme & 5 & 4.13 \\
\hline Diğer & 1 & 0.83 \\
\hline
\end{tabular}

*121 katılımcı arasından ilgili kategoriyi seçenlerin yüzdesidir. Katılımcılar birden fazla kategoriyi seçebilmektedirler.

Tablo 18'e göre, Çince okuma-anlama derslerinde en sık yapılan etkinlik metinle ilgili konuşmadır, öğrencilerin yaklaşık \% 80’i bu etkinliğin daha sık yapıldı̆̆ını belirtmişlerdir. Diğer etkinliklerin daha seyrek yapıldığı belirtilmektedir. Çince okuma-anlama derslerinde sınıf içi etkinliklerde öğretmenin öğrencilere soru sorma sıklığının dağılımı Tablo 19'da verilmiştir. 
Tablo 19. Çince Okuma-Anlama Derslerinde Öğretmenin Soru Sorma S1klığı

\begin{tabular}{|l|c|c|}
\hline Kategori & N & \% \\
\hline Sik sik & 75 & 61.98 \\
\hline Bazen & 45 & 37.19 \\
\hline Hiç & 1 & 0.83 \\
\hline Toplam & 121 & 100 \\
\hline
\end{tabular}

Tablo 19'da görüldüğü üzere, öğrencilerin \% 61.98'i öğretmenin Çince okuma-anlama derslerinde sık s1k soru sorduğunu belirtirken, \% 37.19'u ise bazen soru sorduğunu belirtmiştir. Bu bulguya göre, öğretmenler genel olarak Çince okuma-anlama derslerinde öğrencilere soru sormaktadır.

Öğrencilerin Çince okuduğunu anlamada zorlandıkları durumlar Tablo 20’de özetlenmiştir.

Tablo 20. Öğrencilerin Çince Okuduğunu Anlamada Zorlandıkları Durumlar

\begin{tabular}{|c|c|c|}
\hline Kategori & $\mathbf{N}$ & $\%$ \\
\hline Ayrıntılı okumak /metnin tümünü anlamaya yönelik okuma & 45 & 38.79 \\
\hline Dilbilgisi konularını kavramak & 25 & 21.55 \\
\hline Sözcükleri ayırt etmek ve tanımak & 25 & 21.55 \\
\hline Ana fikri bulmak & 8 & 6.90 \\
\hline Yüzeysel okumak/ yaygın okuma & 7 & 6.03 \\
\hline Metnin konusunu anlamak & 6 & 5.17 \\
\hline Toplam & 116 & 100 \\
\hline
\end{tabular}

Tablo 20’ye göre, öğrenciler en çok ayrıntılı okuma yaparken zorlanmaktadırlar (\% 38.79). Dilbilgisi konularını kavrama (\% 21.55) ve sözcükleri tanıma (\% 21.55) öğrencilerin zorlandıkları diğer önemli iki durumdur. Öğrenciler en az metnin konusunu anlamada zorlanmaktadırlar (\%5.17).

Öğrencilerin Çince okuduğunu anlamada zorluk çekmelerinin sebepleri farklılaşmaktadır. Bu sebepler Tablo 21 'de verilmiştir.

Tablo 21. Öğrencilerin Çince Okuduğunu Anlamada Zorluk Çekmelerinin Sebepleri

\begin{tabular}{|c|c|c|}
\hline Kategori & $\mathbf{N}$ & $\%$ \\
\hline Bilmediğim im ve sözcük sayısı fazla & 62 & 54.39 \\
\hline Sözcügün anlamını biliyorum fakat tümceyi anlamıyorum. & 24 & 21.05 \\
\hline Okuma metinlerinin konusu ilgi çekici değil. & 8 & 7.02 \\
\hline Metinlerin dil seviyesi yüksek & 7 & 6.14 \\
\hline Sözcükleri ve sözcük gruplarını ayırt edemiyorum. & 4 & 3.51 \\
\hline Metin türleri ve anlatımları farklı geliyor. & 4 & 3.51 \\
\hline Okuma metinlerinin içeriğine çok yabancıyım. & 3 & 2.63 \\
\hline Diğer & 2 & 1.75 \\
\hline Toplam & 114 & 100 \\
\hline
\end{tabular}


Tablo 21'de görüldüğü üzere, öğrencilerin Çince okuduğunu anlamada zorluk çekmesinin birinci sebebi, bilinmeyen im ve sözcük sayısının fazla olmasıdır ( \% 54.39). Öğrencilerin \% 21.05'i sözcüğün anlamını bilmesine rağmen tümceyi anlamada zorlandığını belirtmiştir. Bazı öğrenciler ise Çince okuduğunu anlamada zorlanmalarını okuma metinlerine bağlamıştır. Öğrencilerin \% 7.02'si metinlerin konusu ilgi çekici olmadığ için zorlanmaktadır. Metinlerin dil seviyesi yüksek olduğu için zorlandığını düşünen öğrencilerin yüzdesi 6.14’tür.

Öğrenciler, Çince okuduğunu anlama sırasında bilmedikleri sözcükle karşılaştıklarında farklı çözüm yollarına başvurmaktadır. Bu çözüm yollarının kullanımına ilişkin elde edilen bulgular Tablo 22'de verilmiştir.

Tablo 22. Bilinmeyen Sözcükle Karşılaşıldığında Öğrencilerin Yaptığı Davranışlar

\begin{tabular}{|c|c|c|}
\hline Kategori & $\mathbf{N}$ & $\%$ \\
\hline Hemen sözlüğe bakarım. & 49 & 40.83 \\
\hline Okumaya devam edip tahmin etmeye çalışırım. & 28 & 23.33 \\
\hline Sözcüğün parçasına (radikal-部件) bakıp tahmin etmeye çalışırım. & 26 & 21.67 \\
\hline Önce önemsemem, daha fazla karşıma çıkarsa sözlüğe bakarım. & 14 & 11.67 \\
\hline Önemsemem sadece okumaya devam ederim. & 2 & 1.67 \\
\hline Diğer & 1 & 0.83 \\
\hline Toplam & 120 & 100 \\
\hline
\end{tabular}

Tablo 22'ye göre, bilmedikleri sözcükle karşılaştıklarında öğrencilerin en çok yaptığı davranış sözlüğe bakmaktır ( \% 40.83). Öğrencilerin \% 23.33’ü okumaya devam ederek bilinmeyen sözcüğü tahmin etmeye, \% 21.67'si ise sözcüğün parçasına bakarak sözcüğü tahmin etmeye çalışmaktadır. Öğrencilerin \% 11.67'si sözcükle ilk karşılaştığında hiçbir eylemde bulunmayıp tekrar karşılaştığında sözlüğe bakacağını ifade etmiştir.

Öğrencilerin Çince okuma-anlama derslerinde tercih ettikleri yazınsal metin türlerine ilişkin bulgular Tablo 23 ’te verilmiştir.

Tablo 23. Öğrencilerin Çince Okuma-Anlama Derslerinde Tercih Ettikleri Yazınsal Metin Türleri

\begin{tabular}{|l|c|c|}
\hline Yazınsal Metin Türü & $\mathbf{N}$ & $\mathbf{\%}^{*}$ \\
\hline Hikâye & 77 & 63.64 \\
\hline Tarihi metinler & 32 & 26.45 \\
\hline Roman & 29 & 23.97 \\
\hline Masal & 29 & 23.97 \\
\hline Çizgi roman & 24 & 19.83 \\
\hline Edebi metinler & 24 & 19.83 \\
\hline Biyografi & 19 & 15.70 \\
\hline Anı & 18 & 14.88 \\
\hline Şiir & 12 & 9.92 \\
\hline Diğger & 1 & 0.83 \\
\hline
\end{tabular}

*121 katılımcı arasından ilgili kategoriyi seçenlerin yüzdesidir. Katılımcılar birden fazla kategoriyi seçebilmektedirler. 
Tablo 23’te görüldüğü üzere, öğrencilerin Çince okuma-anlama derslerinde en çok tercih ettikleri yazınsal metin türü hikâyedir ( \%63.64). Daha sonra sırasıyla tarihi metinler (\% 26.45), roman (\% 23.97), masal (\% 23.97), çizgi roman ( $\% 19.83)$, edebi metinler ( $\% 19.83)$, biyografi (\% 15.70), anı (\% 14.88) ve şiir (\% 9.92) gelmektedir.

Öğrencilerin Çince okuma-anlama derslerinde tercih ettikleri bilgi verici metin türlerine ilişkin bulgular Tablo 24'te verilmiştir.

Tablo 24. Öğrencilerin Çince Okuma-Anlama Derslerinde Tercih Ettikleri Bilgi Verici Metin Türleri

\begin{tabular}{|c|c|c|}
\hline Bilgi Verici Metin Türü & $\mathbf{N}$ & $\% *$ \\
\hline Haber yazıları & 58 & 47.93 \\
\hline Makale & 36 & 29.75 \\
\hline Reklamlar, menüler, ilanlar (günlük hayatta karşımıza çıkan metinler) & 34 & 28.10 \\
\hline Deneme & 32 & 26.45 \\
\hline Bilimsel yazılar & 25 & 20.66 \\
\hline Eleştiri & 16 & 13.22 \\
\hline Köşe yazıları & 16 & 13.22 \\
\hline Diğer & 2 & 1.65 \\
\hline
\end{tabular}

*121 katılımcı arasından ilgili kategoriyi seçenlerin yüzdesidir. Katılımcılar birden fazla kategoriyi seçebilmektedirler.

Tablo 24'e göre, öğrencilerin Çince okuma-anlama derslerinde en çok tercih ettikleri bilgi verici metin türü haber yazılarıdır (\% 47.93). Daha sonra sirasıyla makale (\% 29.75), günlük hayatta karşılaşıla metinler ( $\% 28.10)$, deneme (\% 26.45), bilimsel yazılar ( $\% 20.66)$, köşe yazıları (\% 13.22) ve eleştiri (\% 9.92) gelmektedir. Öğrencilerin Çince okuma-anlama derslerinde tercih ettikleri yaklaşıma ilişkin bulgular Tablo 25 'te verilmiştir.

Tablo 25. Öğrencilerin Çince Okuma-Anlama Derslerinde Tercih Ettikleri Yaklaşım

\begin{tabular}{|l|c|c|}
\hline Yaklaşım & $\mathbf{N}$ & $\mathbf{\%}$ \\
\hline $\begin{array}{l}\text { Etkileşimsel (Sözcüklerin anlamını öğrenerek, metnin vermek iștediği anlamı artalan } \\
\text { bilgisi ile ilişkilendirerek anlamaya çalışmak) }\end{array}$ & 35 & 29.66 \\
\hline $\begin{array}{l}\text { Parçadan bütüne (Her imin anlamını ve sesletimini öğrenerek metni anlamaya } \\
\text { çalışmak) }\end{array}$ & 31 & 26.27 \\
\hline Hepsi & 31 & 26.27 \\
\hline $\begin{array}{l}\text { Bütünden parçaya (Metni bütün olarak düşünüp, sözcük anlamından çok metin } \\
\text { anlamına ulaşmaya çalışmak) }\end{array}$ & 21 & 17.80 \\
\hline Toplam & 118 & 100 \\
\hline
\end{tabular}

Tablo 25'te görüldüğü üzere, öğrencilerin \% 29.66'sı etkileşimsel yaklaşımı tercih etmektedir. Öğrencilerin \% 26.27'si parçadan bütüne yaklaşımını tercih ederken \% 17.80'i bütünden parçaya yaklaşımını tercih etmektedir. Tüm yaklaşımları tercih eden öğrencilerin yüzdesi $26.27^{\text {'dir. }}$

Öğrencilerin okuma öncesinde kullandıkları Çince okuduğunu anlama stratejilerine ilişkin bulgular Tablo 26' da verilmiştir. 
Tablo 26. Öğrencilerin Okuma Öncesinde Kullandıkları Çince Okuduğunu Anlama Stratejileri

\begin{tabular}{|c|c|c|}
\hline Strateji & $\mathbf{N}$ & $\% *$ \\
\hline Bilinmeyen sözcükleri çıkarma & 89 & 73.55 \\
\hline Metne göz gezdirerek konusunu tahmin etme & 54 & 44.63 \\
\hline Okuma amacını belirleme & 19 & 15.70 \\
\hline Metnin yazarı hakkında bilgi sahibi olmak & 8 & 6.61 \\
\hline Diğer & 1 & 0.83 \\
\hline
\end{tabular}

*121 katıllmcı arasından ilgili kategoriyi seçenlerin yüzdesidir. Katılımcılar birden fazla kategoriyi seçebilmektedirler.

Tablo 26'da görüldüğü üzere, öğrencilerin okuma öncesinde en s1k kullandıkları Çince okuduğunu anlama stratejisi, bilinmeyen sözcükleri çıkarmaktır ( \% 73.55). Öğrencilerin sık kullandıkları diğer bir strateji ise metne göz gezdirerek metnin konusunu tahmin etmeye çalışmaktır ( $\%$ 44.63).

\subsection{Anadil Konuşucusu Öğretmen Sormacalarından Elde Edilen Bulgular}

Nanjing Üniversitesi Çin Dili ve Edebiyatı bölümünde ve Çince dil kursunda öğretmenlik yapan 10 Çinli öğretmene ikisi açık uçlu, 28 çoktan seçmeli maddeden oluşan sormaca uygulanmıştır. "Anadil konuşucusu öğretmenlerin okuma-anlama becerilerine ilişkin görüşleri nelerdir?" sorusuna yanıt aranmıştır. Çinli öğretmenlerden toplanan sormaca bulguları, mevcut programı değerlendirme, okuma-anlama strateji ve teknikleri, okuma araçları, metin türleri ve sınama türleri olmak üzere beş etmene göre 10 kişi üzerinden sayısal değerleri verilerek bulgular sunulmuş ve yorumlanmıştır.

Anadil konuşucusu öğretmenlerin mevcut programa ve okuma-anlama becerilerine ilişkin görüşlerini içeren bulgular aşağıda sunulmuştur.

Öğretmenlerden 6'sı becerilerin eşit olması gerektiğini düşünürken 2 kişi okuma, 2 kişi dinleme ve konuşma seçeneklerini işaretlemişler (Madde 1). Öğretmenlerden 8'i okuma dersi planlanırken öğrencilere sorulması gerektiği seçeneğini işaretlerken, 2 öğretmen Çince hazırlanmış planların yeterli olduğunu seçeneğini işaretlemiştir (Madde 2). Anadil konuşucusu öğretmenler her ne kadar ders planlamasında öğrenci görüşlerine önem verdiklerini belirtmiş olsalar da, uygulamada öğrenci görüşlerinin sorulduğuna rastlanmamıştır.

Öğretmenlerden 3'ü okuma öğretimine ilişkin ders almadım, seçeneğini işaretlerken 7 öğretmen yabancı dil olarak okuma-anlama öğretimine ilişkin eğitim aldım seçeneğini işaretlemiştir (Madde 3). Öğretmenlerin çoğunluğu okuma öğretimi dersleri almıştır.

Mevcut programda eksik buldukları beceri olarak öğretmenlerden 5'sı yazma, 3'ü dinleme, 1'i konuşma, 1'i okuma becerisi seçeneklerini işaretlemişlerdir (Madde 4). Yazma ve yazılı anlatım becerisi Çince öğretiminde en zor ve en son gelişen beceri olması nedeniyle öğretmenlerin yazma becerisini seçmeleri beklenen bir sonuçtur.

Öğretmenler okuma-anlama derslerinde yazınsal metin türlerinden hikâye (9), masal (7); bilgilendirici metin türünde ise haber (8), deneme (7) kullanmanın faydalı olacağını 
düşünmektedirler (Madde 14). Öğretmenler tarafından en çok tercih edilen metin türü hikâye ve masal olsa da, lisans düzeyinde öğrencilerin çeşitli güncel ve sık karşılaşılan metin türlerini okumaları beklenir.

Öğretmenlerin okuma-anlama derslerinde en sık yaptırdıkları stratejiler, okuma öncesi sözcükleri çalıştırma (7); okuma sırası bilinmeyen sözcüğün tahmin edilmesi (7); okuma sonrası dilsel yapıların kullanımı anlatma (6), ana fikri bulma (4), metni sözlü anlatma (5) seçenekleri olarak sıralanabilir (Madde 15). Öğretmenlerin sık yaptıkları okuma teknikleri ise ayrıntılı okuma (10), tarama (8), gözden geçirme (6) şeklindedir (Madde 16). Okuma-anlama derslerinde sık sık ön bilgi verdiklerini (10) ve ön bilgi verirken dinleme etkinliklerine (7) başvurdukları anlaşılmaktadır (Madde 18 - 19). Bu sonuçlar anadil konuşucusu öğretmenlerin okuma-anlama derslerinde sözcük ve dilsel bilgi öğretmeye daha çok önem verdikleri ve sözcük öğretme stratejileri kullandıklarını gösterir.

\subsection{Türk Öğretmenlerin Görüșleri}

Bu araştırmada, Çince programlarda ders veren 6 Türk öğretmen ile yarı yapılandırılmış görüşme yapılmıştır. Görüşmede açık uçlu soruların bulunduğu görüşme çizelgesi kullanılmış,

görüşmelerin ses kaydı alınmıştır. Görüşmede, öğretmenlerin okuma-anlama becerileri, dersleri, okuma-anlama stratejileri, ders araçları hakkında görüşleri belirlemek amaçlanmıştır.

Öğretmenlerin ders içi etkinlik ve uygulamalara ilişkin görüşlerini almak amacıyla "Çince okuduğunu anlama etkinliklerini verimli hale getiren etmenler nelerdir?” sorusu yöneltilmiştir. Öğretmenlerin verdiği aşağıdaki yanıtlara göre, öğrencilerin motivasyonu, istekli olması, derse hazır olması ve ders araçları ders verimliliğini etkilemektedir.

Öğretmen görüşlerinden elde edilen bulgulara göre, öğretmenlerin hepsi derslerin verimli geçmesinde veya geçmemesinde sorumluluğu büyük ölçüde öğrenci isteğine, motivasyonuna bağlamaktadır.

Öğretmenlerden başlangıç düzeyde sık kullanılan sözcük ve tümce anlama bağlamında kalan sınama türleri tümce kurma, boşluk doldurma, yazma gibi öneriler gelmiştir. Öğretmenlerden gelen cevaplarda ortak olan bir durum çevirinin sınama türü olarak oldukça yaygın kullanıldığıdır. Çevirinin öğretmenlerden tarafından yaygın şekilde tercih edilmesi geleneksel yöntemle eğitimin sürdürüldüğünü göstermektedir.

Öğretmenler özellikle ilkokul, ortaokul ve lise düzeyinde öğrenciler için görsel ve işitsel etkinlik çeşitliliğinin önemine vurgu yapmıştır. Dersi verimli hale getirmek için kendileri etkinlik üretmeye çalıştıklarını ve ders kitabının olmadığını ve olsa bile yeterli gelmediğini ifade etmişlerdir. Lisans düzeyinde derslere giren öğretmenlerin ders kitaplarındaki etkinliklere bağlı kaldıkları görülmektedir. Genel olarak öğretmenlerin hepsi ders araçlarını yetersiz bulduklarını, ders araçlarının niteliğinin iyi olmadığını, uygun aracı bulamadıklarını ifade etmiştir. 


\subsection{Mezun Öğrenci Görüşleri}

Üç araştırma görevlisi ve 2 iş arayan mezun öğrenci, 3 doktora öğrencisi (Çin'de) ve 1 dış ticaret bölümünde, 1 mermer sektöründe çalışan olmak üzere, toplam 10 mezun öğrenci ile odak grup görüşmeleri yapılmıştır. Mezun olduktan sonra Çince ile ilgili iş yapıyor olma veya Çince eğitimlerine devam ediyor olma durumları dikkate alınarak çalışmamıza katılan mezun öğrencilerin okuma-anlama dersi ve etkinliklerine ilişkin görüşlerine ulaşmak amaçlanmıştır. Mezun odak grup görüşmesinde 11 açık uçlu soruya yer verilmiştir.

Mezun öğrenci odak grup görüşmesi kayıt altına alınarak değerlendirilmiştir. Mezun odak grup görüşmesi, grup halinde yapılmış, gruplardan alınan yanıtlar değerlendirilmiştir.

Özet olarak mezun öğrenciler, okuma-anlama derslerinde içerik bilgisi ve sözcük bilgisinin önemli olduğunu ifade etmişler ve ayrıca özellikle öğretmenlerin öğrencilere rehberlik etmeleri, ders ve ders dişı farklı kaynaklar okumaya teşvik etmeleri, çeşitli strateji ve teknikler kullanmayı öğretmeleri gerektiğini vurgulamışlardır.

Mezun öğrencilere yöneltilen sorulardan biri de "Çince okuma-anlama derslerinde hangi metin türlerini okumuş olmayı isterdiniz?" sorusu yöneltilmiştir. Mezun öğrencilerden;

"Tarihî metinler, makale","Bilimsel makaleler, basın metinlerini, köşe yazıları, kültürel metinler, kitap, film yorumları, eleştirileri”, "Öyküler, anılar, edebi eserler, günlük kısa metinler, e-postalar, mesajlar, diyaloglar, ilginç hikâyeler..." yanıtları alınmıştır.

Mezun öğrencilerin öneri ve görüşlerine göre, okuma derslerinin dönem başında planlanması, kullanılan araçların, metinlerin güncel seçilmesi, sınıf içi, sınıf dışı etkinlik ve uygulamaların çeşitlendirilmesi gerektiği açıkça görülmektedir. İş yaşamına başladıktan sonra mezun öğrencilerin metin türlerine ilişkin görüşleri farklılaşmış ve güncel, kullanımlık metinlerin oldukça önemli olduğu fikri kabul edilmiş̧ir.

Çalışma alanına ve bölüme göre dil becerilerinin kullanım yoğunluğu farklı olsa da, Çince öğrenmeye ve meslek hayatında kullanmaya devam eden mezun öğrencilerin başarılı şekilde iş ve meslek hayatlarını sürdürmek için okuma becerilerine yoğun olarak ihtiyaç duydukları anlaşılmaktadır.

\section{Sonuç ve Öneriler}

Araştırma sorularına göre elde edilen bulgulara göre aşağıdaki sonuçlara ulaşılabilir.

Öğrencilerin bir kısmı mezun olurken HSK 6 seviyeyi hedeflerken, bir kısmı ise HSK 5 düzeye ulaşmayı hedeflemektedir. Öğrencilerin hedefledikleri HSK 5/6 seviye oranlarının birbirine yakın olduğu gözlenmiş̧ir. Öğrencilerin hedefledikleri dil düzeyleri HSK dil seviyeleri ile örtüşmektedir. HSK 5 (5+) seviye kazanımlarına göre içerik oluşturma gerekliliği ortaya çıkmıştır.

Öğrencilerin büyük çoğunluğuna göre, okuma-anlama derslerinde öğretmenler, okumaanlama becerisinin geliştirilmesi için strateji ve tekniklerle dolu etkinliklere öncelik vermelidir. 
Mezun öğrenciler de aynı görüşü desteklemektedir. Çok sayıda çeşitli etkinliklerle strateji ve teknik farkındalığının arttırılması gerekir. Öğrencilerin stratejilerin öneminin farkında olmalarına rağmen öğretmenlerin yeterli strateji, teknik kullanmadıkları görüşme sonuçlarından anlaşılmıştır. Öğretmenlerin derslerde çoğunlukla sözcük öğrenme stratejilerine yer verirken, anlama odaklı stratejilerine daha az yer verdikleri ortaya çıkmıştır. Öğretmenlerin özellikle strateji, teknik ve etkinlik konularında farkındalık kazanmaları gerektiği ortaya çıkmıştır. Ancak öğretmenler rehberlik ederse, öğrenciler etkili strateji ve teknikleri kullanmayı öğrenip okuduğunu anlama becerilerini geliştirebilir. Öğrenme stratejileri, öğretmenlerin rolünü genişletir. Geleneksel öğretmenlerin otoriter ve baskın olması beklenirken, öğretmenler öğrencilerin daha bağımsız, özgür olmalarına yardım etmeli ve öğrencilerin öğrenme stratejilerini tanımlayıp, rehber, danışman rollerini üstlenmelidir. ${ }^{14}$

Öğrencilerin büyük çoğunluğunun, okuma öncesi bilinmeyen sözcükleri çıkarma stratejisini kullandıkları sonucuna ulaşılmış ve okuma öncesi yeni, çeşitli stratejilere gereksinimleri olduğu bulunmuştur. Okuma sırası stratejileri arasından öğrenciler bilinmeyen sözcükleri tahmin etme, önemli bulduklarını yerlerin altını çizme ve okuduklarını zihinde canlandırma stratejilerini kullandıklarını belirtmişlerdir. Okuma öncesi ve okuma sonrası strateji farkındalığının sağlanması ve çeşitliliğin arttırılması gerektiği sonucuna ulaşılmıştır. Öğrenciler uygun strateji, teknik ve etkinliklerle okuduğunu anlama becerilerini geliştirebileceklerinin farkındadırlar ve daha fazla strateji ve teknik öğrenme ve uygulama gereksinimleri bulunmaktadır.

Öğrenci ve öğretmenlerin tercih ettiği ortak metin türleri hikâye, anlatı ve haber metinleridir. Mezun öğrenciler ise e-posta, mesaj vb. farklı metin türlerini önermişlerdir. Mezun öğrenciler, iş ve meslek hayatı içinde bulundukları için önerileri önemlidir. Öğrenci ve öğretmenlerin çoğunlukla yazınsal metin türlerine yönelmeleri, farklı metin türlerine ilişkin farkındalıklarının daha az olduğunu gösterir, dolayısıyla çeşitli metin türlerine ilişkin farkındalık kazanmaları ve derslerde kullanmaları gerekli görülmektedir. Öğrencilerin sık kullanmak istedikleri araçlar özgün araçlar iken derste kullanım oranları düşüktür. Öğrencilerin neredeyse yarısı Çince çalışırken youtube kullandığı anlaşılırken öğrencilerin bir bölümü Çin’e özgü sitelerinden haberdar değildir. Bu durumda öğrencilerin sınıf içinde ve sınıf dışında daha fazla internet ortamlarını kullanma, özgün araçları okuma gerekliliği bulunmuştur.

Okuma derslerinde öncelikle ders amaçlarının ve okuma hedeflerinin net olarak belirlenip (sözcük öğretmek, beceri geliştirmek) öğrencilerle görüşülmelidir. Öğrencilerin, okumanın sadece sözcükleri anlamak olmadığının farkına varmaları amacıyla, etkinliklerde çeşitli strateji ve teknikler kullanması önerilmektedir. Okuma stratejilerinin öğrencilere öğretilmesi, çeşitli stratejilere yönelik farkındalıklarının geliştirilmesi ve etkili strateji kullanmalarının sağlanması gerektiği düşünülmektedir. Bu durumda öğretmenlere, okuma strateji ve teknikleri konusunda öğrencilerini bilgilendirmeleri, derste düzenli şekilde uygulamaları ve sonucu sınamaları önerilmektedir.

14 R. L. Oxford, Language learning strategies: What every teacher should know, New York: Newbury House, 1990 . 
Metin türleri bakımından, öğrencilerin farklı türlerle karşılaşması ve türlere uygun okuma yapmaları, öğrencilerin okuma ilgilerini arttırır, güdülenme sağlar. Sınıf içine çeşitli metin türlerinin taşınması ve öğrencilere de metin seçme firsatının tanınması önerilir.

Hakem Değerlendirmesi: Dış bağımsız.

Çıkar Çatışması: Yazar çıkar çatışması bildirmemiştir.

Finansal Destek: Yazar bu çalışma için finansal destek almadığını beyan etmiştir.

Peer-review: Externally peer-reviewed.

Conflict of Interest: The author has no conflict of interest to declare.

Grant Support: The author declared that this study has received no financial support.

\section{Kaynakça/References}

Brown, J. D. Using Survey in Language Programs. Cambridge: Cambridge Language Teaching Library, 2001.

Dörnyei, Z. Questionnaires in Second Language Research: Construction, Administration and Processing. London: Lawrence Erlbaum Associates P. 2003.

Grabe, W. \& Stoller, F. L. Teaching and Researching Reading (2nd ed.). Great Britain: Pearson, 2011.

Greene, J. C. Caracelli, V. J. \& Graham, W. F.. "Toward a Conceptual Framework for Mixed-Method Evaluation Design”, Educational Evaluation and Policy Analysis. 11(3): 255-274, 1989.

Grier, A.S. "Integrating needs assesment into career and technical curriculum development”, Journal of Industrial Teacher Education. 42(1): 59-66, 2005.

Harmer, J. The Practice of English Langugae Teaching. England: Pearson Education Limited, 2007.

Huntchinson, T. \& Waters, A. English for Specific Purposes: A learning- centered approach. Newyork: Cambridge University, 1991.

Krashen, S. D. Principles and Practice in Second Language Acquisition. Pergamon Press, 1982.

Lapp, D., \& Flood, J. Teaching Student to Read. NY: Macmillan Publishing Company, 1986.

Liang, F. "Adopting mixed methods for research topics in teaching Chinese as a second/foreign language", RTCFL. 2(2): 109-122, 2016.

Long, M. H. Second Language Needs Analysis. UK: Cambridge University Press, 2005.

Nunan, D. Second language teaching \& learning. Boston: MA: Heinle \& Heinle.1999, p.149.

Richard, J. C. The Language Teaching Matrix. NY: Cambridge University Press, 1990.

Oxford, R. L., Language learning strategies: What every teacher should know. New York: Newbury House.1990.

Zhang, Dongbo. "Word Reading in L1 and L2 Learners of Chinese: Similarities and Differences in the Functioning of Component Processes", Modern Language Journal. 101(2):391-411, 2017. 
